\title{
Latent membrane protein 1 (LMP1) expression in Hodgkin lymphoma and its correlation with clinical and histologic parameters
}

Atif Ali Hashmi', Zubaida Fida Hussain ${ }^{1}$, Kashif Ali Hashmi², Muhammad Irfan Zafar', Muhammad Muzzammil Edhi ${ }^{4}$, Naveen Faridi ${ }^{1}$ and Mehmood Khan ${ }^{5 *}$

\begin{abstract}
Background: Hodgkin lymphoma is one of the most prevalent lymphoproliferative disorders in Pakistan; however, no risk factors for this disease have yet to be established in our population. Epstein-Barr virus (EBV) is a well-known risk factor for Hodgkin lymphoma in endemic regions of the world; however, frequency of its association in our population has not been widely studied. Latent membrane protein 1 (LMP1) expression by immunohistochemistry $(\mathrm{IHC})$ is a surrogate marker of EBV in Hodgkin lymphoma. Therefore, we aimed to evaluate the frequency of expression of LMP1 in cases of Hodgkin lymphoma at our institute and its correlation with other clinical and histologic parameters.

Methods: The study included 66 cases of Hodgkin lymphoma diagnosed at Liaquat National Hospital over a duration of 2 years from January 2014 to December 2015. The slides and blocks of all cases were retrieved, and representative blocks were selected for LMP1 by IHC. LMP1 expression of $>10 \%$ of cells was considered as positive expression and correlated with histologic subtypes and clinical parameters like age, gender, and site of involvement.

Results: The mean age of patients was 35.11 (+20.22). LMP1 expression was found in $68.1 \%(45 / 66)$ of cases of Hodgkin lymphoma. Mean age of the patients with LMP1 expression was 32.04 (+21.02). LMP1 expression was found in $40 \%$ cases of lymphocyte-rich, $66.7 \%$ of lymphocyte-depleted, $7 \overline{3.9 \%}$ of mixed cellularity, $66.7 \%$ of nodular sclerosis, and $73.7 \%$ of classic Hodgkin lymphoma, NOS. No significant correlation of LMP1 expression with any clinical or histological parameter could be established in our studied patient population.

Conclusions: A high frequency of expression of LMP1 is seen in cases of Hodgkin lymphoma at our setup comparable to endemic regions of the world; therefore, preventive and treatment protocols should be designed accordingly.
\end{abstract}

Keywords: Hodgkin lymphoma, Epstein bar virus (EBV), Latent membrane protein 1 (LMP1), Pakistan

\footnotetext{
* Correspondence: mehmoodkhan955@yahoo.com

${ }^{5}$ Department of Medicine, Dhaka University, Dhaka, Bangladesh

Full list of author information is available at the end of the article
} 


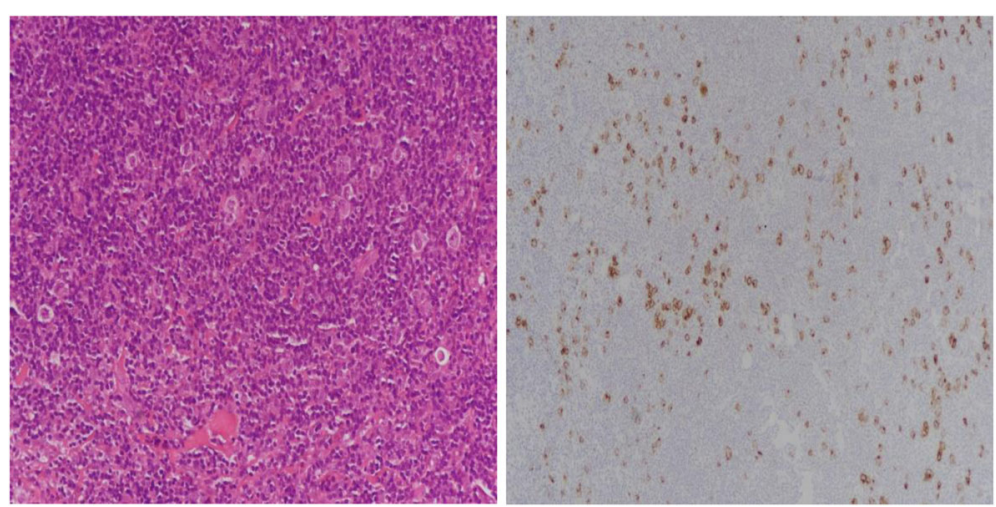

Fig. 1 Mixed cellularity Hodgkin lymphoma with positive LMP1 expression noted in Reed-Sternberg cells

\section{Background}

Hodgkin lymphoma (HL) is a neoplasm of germinal center and post germinal center B cells. It has a unique cellular composition which forms the basis of various histologic subtypes [1]. The association of HL and Epstein-Barr virus (EBV) was first demonstrated on the basis of increased frequency of HL in patients with history of infectious mononucleosis [2, 3] .This concept was further substantiated by detection of EBV in neoplastic Hodgkin Reed-Sternberg (HRS) cells [4-6]. Finally, a populationbased cohort study established the increased relative risk of EBV-positive HL in patients with infectious mononucleosis [7].

$\mathrm{HL}$ is one of the most prevalent lymphoproliferative disorders in Pakistan; however, no risk factors for this disease have yet to be established in our population [8]. Although EBV is a well-known risk factor for HL in endemic regions of the world, frequency of its association in our population has not been widely studied. There are various methods of detecting EBV in HL including immunohistochemistry (IHC), in situ hybridization (ISH), and polymerase chain reaction (PCR) [9]. EBV-infected tumor cells express a subset of EBV genes including latent membrane protein 1 (LMP1), LMP2a, EBV nuclear antigen 1 (EBNA1), EBV small nuclear RNA transcripts (EBER), and the BamHI A region transcripts [10-12]. EBER and LMP1 are the two EBV markers most commonly used in epidemiologic studies in HL [13]. Therefore, we aimed to evaluate the frequency of expression of latent membrane protein 1 (LMP1) in cases of Hodgkin lymphoma at our institute and its correlation with other clinical and histologic parameters.

\section{Methods}

The study included 66 cases of Hodgkin lymphoma diagnosed at Liaquat National Hospital over a duration of 2 years from January 2014 to December 2015. The study was approved by the Institutional Ethical Review Committee of Liaquat National Hospital. The slides and blocks of all cases were retrieved and reviewed by two senior histopathologists with more than 5 years experience of reporting surgical pathology. One representative block of each case was selected for immunohistochemistry by LMP1. LMP1 expression of $>10 \%$ of cells was considered as positive expression (Fig. 1) and correlated with histologic subtypes and clinical parameters like age, gender, and site of involvement.

\section{Results}

The mean age of patients was $35.11( \pm 20.22)$. Male to female ratio was $2: 1$. 86.3\% (57/66) cases were nodal, and mixed cellularity HL was the most common subtype accounting for $34.8 \%$ of cases $(23 / 66)$ as shown in Fig. 2. LMP1 expression was found in $68.1 \%(45 / 66)$ of cases of Hodgkin lymphoma. Mean age of the patients with LMP1 expression was $32.04( \pm 21.02)$ while those with negative LMP1 was $41.67( \pm 17.03)$. No significant correlation was found between LMP1 expression and various demographic parameters (Table 1). LMP1 expression was found in $40 \%$ cases of lymphocyte-rich, $66.7 \%$ of

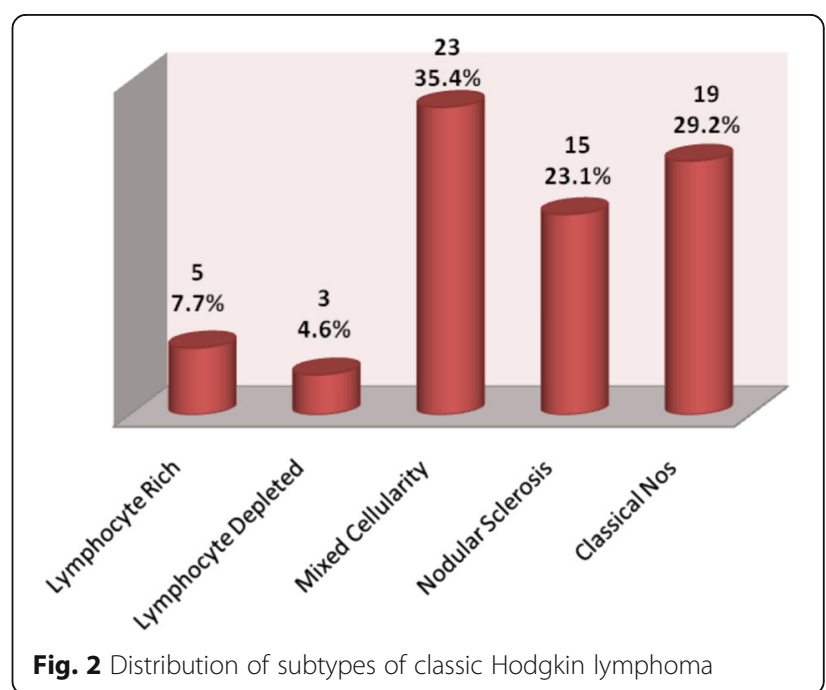


Table 1 Demographic and clinical characteristics of patients involved in the study $(n=66)$

\begin{tabular}{lllll}
\hline & LMP positive & LMP negative & Total & $P$ value \\
& $N(\%)$ & $N(\%)$ & & \\
\hline $\begin{array}{lllll}\text { Age group } \\
\leq 30\end{array}$ & $23(76.7)$ & $7(23.3)$ & 30 & $0.435^{* *}$ \\
$31-60$ & $12(61.3)$ & $216(38.7)$ & 31 & \\
$>60$ & $3(60)$ & $2(40)$ & 5 & \\
Gender & & & & \\
$\quad$ Male & $32(71.1)$ & $13(28.9)$ & 45 & $0.455^{* *}$ \\
Female & $13(61.9)$ & $8(38.1)$ & 21 & \\
Site & & & & \\
$\quad$ Nodal & $37(64.9)$ & $20(35.1)$ & 57 & $0.252^{* *}$ \\
Extra nodal & $8(88.9)$ & $1(11.1)$ & 9 & \\
Diagnosis & & & & \\
Classical Hodgkin & $45(69.2)$ & $20(30.8)$ & 65 & $0.318^{* *}$ \\
NLPHL & $0(0)$ & $1(4.8)$ & 1 & \\
\hline
\end{tabular}

Chi square applied

**not significant at 0.05 levels

lymphocyte-depleted, $73.9 \%$ of mixed cellularity, $66.7 \%$ of nodular sclerosis, and $73.7 \%$ of classic Hodgkin lymphoma, NOS (Fig. 3, Table 2).

\section{Discussion}

In the current study, we evaluated the association of LMP1 expression in HL which is one of the most common lymphomas in Pakistan. Liaquat National Hospital is one of the largest tertiary care hospitals in Pakistan and represents patient population from both the urban and rural areas of the province. Various studies have demonstrated that EBV positivity in $\mathrm{HL}$ is associated with socioeconomic status [14]. Similarly, incidence of EBV-positive HL is higher among underdeveloped countries like Peru and Kenya as compared to developed countries like the USA and Europe [15-18]. This higher incidence of EBV-positive HL may be linked with underlying immunosuppression in underdeveloped regions or may be associated with timing of EBV infection. This later explanation is supported by a higher incidence of EBV-positive HL in children compared with HL in young adults. On the other, a second peak of EBV-positive HL is seen in older adults [19]. High incidence of EBV-positive HL in the elderly population is proposed to be associated with immunosuppression. We found a more homogenous expression of EBV in different age groups. Similarly, we did not find any significant association of EBV positivity with gender, although a few authors demonstrated a higher rate of EBV-positive $\mathrm{HL}$ in females as compared to male patients.

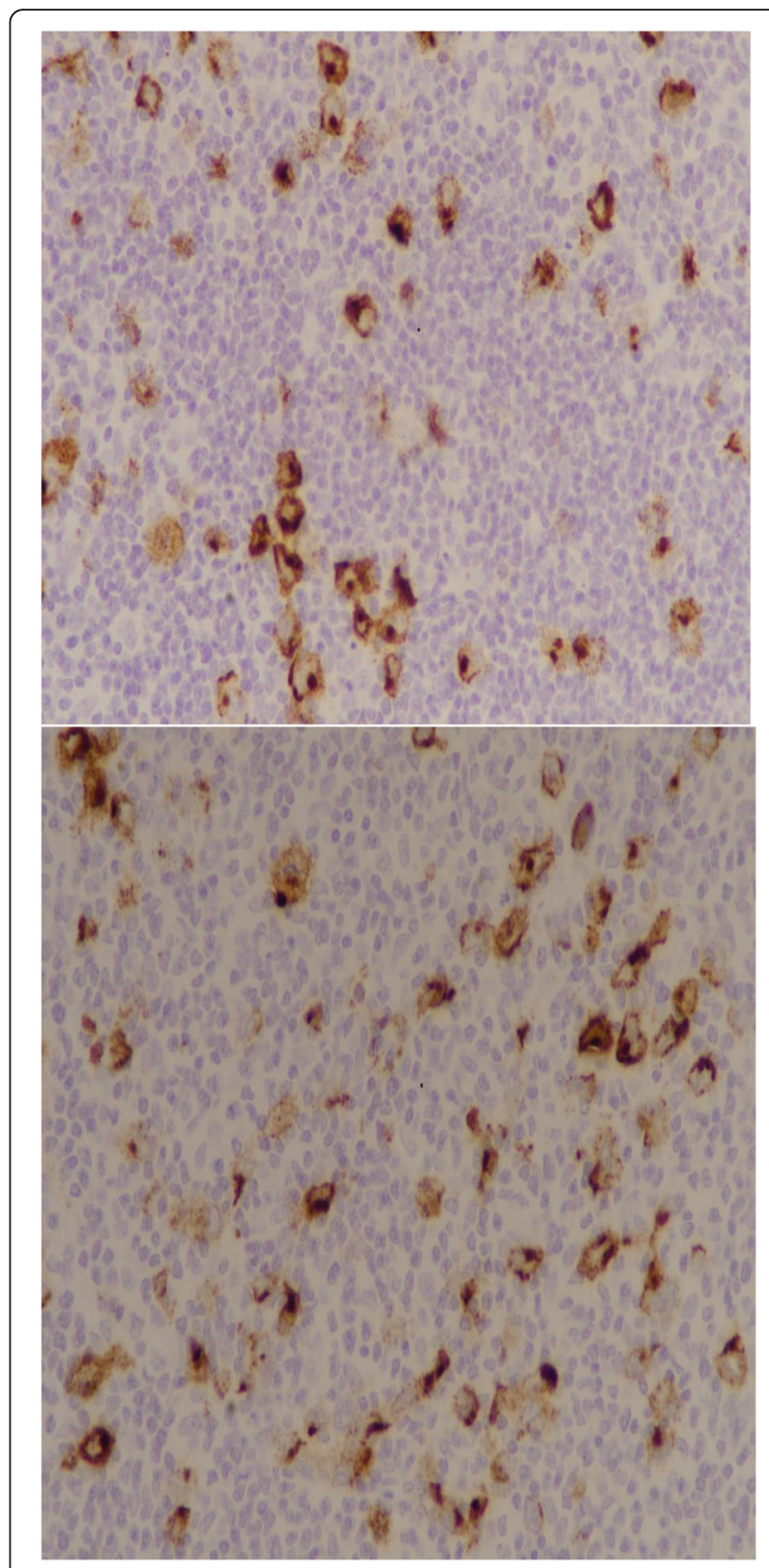

Fig. 3 LMP1 expression in Hodgkin lymphoma. Reed-Sternberg cells are highlighted with LMP1 stain Golgi accentuation (×400 magnification)

Table 2 LMP expression in subtypes of classic Hodgkin $(n=65)$

\begin{tabular}{lllll}
\hline & LMP positive & LMP negative & Total & $P$ value \\
& N (\%) & N(\%) & & \\
\hline Lymphocyte rich & $2(40)$ & $3(60)$ & 5 & $0.651^{\text {** }}$ \\
Lymphocyte depleted & $2(66.7)$ & $1(33.3)$ & 3 & \\
Mixed cellularity & $17(73.9)$ & $6(26.1)$ & 23 & \\
Nodular sclerosis & $10(66.7)$ & $5(33.3)$ & 15 & \\
Classical NOS & $14(73.7)$ & $5(26.3)$ & 19 & \\
\hline
\end{tabular}

Chi-square applied

**not significant at 0.05 levels 
Table 3 Comparison of EBV expression in Hodgkin lymphoma with other countries in South Asia

\begin{tabular}{|c|c|c|c|c|c|c|}
\hline Country & Reference & $\begin{array}{l}\text { Total positive cases of } \\
\text { Hodgkin lymphoma }\end{array}$ & Lymphocyte rich & Lymphocyte depleted & Mixed cellularity & Nodular sclerosis \\
\hline Korea & Park et al. [20] & $17 / 25(68 \%)$ & - & - & $11 / 13(85 \%)$ & $5 / 8(62 \%)$ \\
\hline Saudi Arabia & Armstrong et al. [23] & $7 / 8(88 \%)$ & - & - & $5 / 5(100 \%)$ & $2 / 2(100 \%)$ \\
\hline Pakistan & Fatima S et al. [26] & $50 / 100(50 \%)$ & $0 / 6(0 \%)$ & - & $41 / 57(71 \%)$ & 19/35(54.2\%) \\
\hline China & Zhou XG et al. [21] & $17 / 28(60.7 \%)$ & - & $0 / 1(0 \%)$ & 10/11(90.9\%) & $6 / 14(\%)$ \\
\hline India & Karnic S et al. [24] & $82 / 100(82 \%)$ & - & - & - & $43 / 50(86 \%)$ \\
\hline Jordan & Sughayer MA et al. [25] & $41 / 94(43.6 \%)$ & $0 / 2(0 \%)$ & & 21/26(80.8\%) & 20/66(30.3\%) \\
\hline Malaysia & Peh SC et al. [22] & $41 / 67(61.2 \%)$ & - & $1 / 1(100 \%)$ & 27/31(87.1\%) & 12/33(36.4\%) \\
\hline Pakistan (our study) & Hashmi AA et al. & $31 / 65(47.7 \%)$ & $2 / 5(40 \%)$ & $2 / 3(66.7 \%)$ & 17/23(73.9\%) & 10/15(66.7\%) \\
\hline
\end{tabular}

Table 3 compares the EBV protein expression in our study with other countries of South Asia [20-22]. Most studies show higher frequency of EBV expression as compared to our study. The highest incidence of EBV positivity was noted in India and Saudi Arabia (82 and $88 \%$, respectively) [23, 24]. The lowest expression of EBV was noted in Jordan (43.6\%) [25]. Our results were comparable with those of another study conducted in Pakistan depicting 50\% expression of EBV in Hodgkin lymphoma [26].

Various histologic subtypes of HL are defined on the basis of background lymphoid population, presence of fibrosis, relative percentage of HRS, and immunophenotype. In economically advanced countries like the USA, nodular sclerosis $\mathrm{HL}$ is the most frequent subtype of $\mathrm{HL}$ [27]. On the other hand, mixed cellularity HL is more frequent in the underdeveloped world. Only a few studies have been conducted in Pakistan with regard to HL. A regional study demonstrated the highest frequency of mixed cellularity HL accounting for $63 \%$ of all cases of $\mathrm{HL}$ and absence of bimodal age distribution as seen in our study [28].

Recent studies show that LMP1 expression may be used as a prognostic marker in some cases of Hodgkin lymphoma and therefore targeted therapy may be helpful [29]. Similarly, recent data suggests that EBV DNA expression in peripheral blood may be used as a clinical predictor of disease burden and monitoring response to therapy during disease course [30, 31].

As discussed above, EBV-infected HRS cells express a subset of EBV genes: LMP1, LMP2a, EBNA1, BamHI, and EBER. Studies have found a potential role of LMP1 and EBNA1 in tumor pathogenesis. EBNA1 expression is required for the replication and maintenance of the viral genome in dividing tumor cells [32]. Further role for EBNA1 in the pathogenesis of HL has not been determined. However, LMP1 and LMP2a appear to play a key role in the development of HL. HRS cells harbor crippling mutations in their immunoglobulin (Ig) genes, and due to lack of functional Ig, they are prone to die by apoptosis. Expression of LMP1 or LMP2a helps HRS cells to escape apoptotic mechanisms [33]. Various authors correlated the expression of EBV in HL with histological subtypes. Mixed cellularity HL is more likely to be EBV positive compared to nodular sclerosis HL [34]. A study conducted in Pakistan demonstrated $71 \%$ expression of EBV in mixed cellularity HL compared to $54 \%$ expression in nodular sclerosis subtype [26]. We also found a higher frequency of expression of LMP1 in mixed cellularity HL; however, the results are not statistically significant.

\section{Conclusions}

A high frequency of expression of LMP1 is seen in cases of Hodgkin lymphoma at our setup comparable to endemic regions of the world; therefore, preventive and treatment protocols should be designed accordingly.

\section{Abbreviations}

HL: Hodgkin lymphoma; LMP1: Latent membrane protein 1

\section{Acknowledgements}

We gratefully acknowledge all the staff members of the Department of Pathology, Liaquat National Hospital, Karachi, Pakistan, for their help and cooperation.

\section{Funding}

The Liaquat National Hospital and Medical College, Karachi, Pakistan helped in the design of the study and collection, analysis, and interpretation of data.

Availability of data and materials

Please contact the corresponding author for data requests.

\section{Authors' contributions}

$\mathrm{AAH}$ and $\mathrm{ZFH}$ are the main authors of the manuscript and have made substantial contributions to the conception and design of the study. $\mathrm{KAH}$ and MIZ have been involved in the requisition of the data. MME, NF, and MK have been involved in the analysis of the data and gave final approval and revision of the manuscript. All authors read and approved the final manuscript.

\section{Competing interests}

The authors declare that they have no competing interests.

Consent for publication

The written consent is available for review by the Editor-in-Chief of this journal. 


\section{Ethics approval and consent to participate}

The Ethics Committee of Liaquat National Hospital approved the study. Written informed consent was obtained from the patients for their participation.

\section{Publisher's Note}

Springer Nature remains neutral with regard to jurisdictional claims in published maps and institutional affiliations.

\section{Author details}

'Department of Pathology, Liaquat National Hospital and Medical College, Karachi, Pakistan. ${ }^{2}$ Department of Cardiology, Chaudhry Pervaiz Elahi Institute of Cardiology, Multan, Pakistan. ${ }^{3}$ Department of Biostatistics, Liaquat National Hospital and Medical College, Karachi, Pakistan. ${ }^{4}$ Department of Surgery, Brown University, Providence, RI, USA. ${ }^{5}$ Department of Medicine, Dhaka University, Dhaka, Bangladesh.

\section{Received: 20 December 2016 Accepted: 2 April 2017}

\section{Published online: 20 April 2017}

\section{References}

1. Harris NL, Jaffe ES, Stein H, Banks PM, Chan JK, Cleary ML, Delsol G, De Wolf-Peeters C, Falini B, Gatter KC. A revised European-American classification of lymphoid neoplasms: a proposal from the International Lymphoma Study Group. Blood. 1994;84(5):1361-92.

2. Lehtinen T, Lumio J, Dillner J, et al. Increased risk of malignant lymphoma indicated by elevated Epstein-Barr virus antibodies - a prospective study. Cancer Causes Control. 1993:4:187.

3. Alexander FE, Jarrett RF, Lawrence D, et al. Risk factors for Hodgkin's disease by Epstein-Barr virus (EBV) status: prior infection by EBV and other agents. $\mathrm{Br}$ J Cancer. 2000;82:1117.

4. Staal SP, Ambinder R, Beschorner WE, et al. A survey of Epstein-Barr virus DNA in lymphoid tissue. Frequent detection in Hodgkin's disease. Am J Clin Pathol. 1989:91:1.

5. Wu TC, Mann RB, Charache $P$, et al. Detection of EBV gene expression in Reed-Sternberg cells of Hodgkin's disease. Int J Cancer. 1990:46:801.

6. Weiss LM, Movahed LA, Warnke RA, Sklar J. Detection of Epstein-Barr viral genomes in Reed-Sternberg cells of Hodgkin's disease. N Engl J Med. 1989;320:502

7. Hjalgrim H, Askling J, Rostgaard K, et al. Characteristics of Hodgkin's lymphoma after infectious mononucleosis. N Engl J Med. 2003;349:1324

8. Bhurgri Y, Bhurgri A, Hassan SH, Zaidi SH, Rahim A, Sankaranarayanan R, Parkin DM. Cancer incidence in Karachi, Pakistan: first results from Karachi Cancer Registry. Int J Cancer. 2000;85(3):325-9.

9. Qi ZL, Han XQ, Hu J, Wang GH, Gao JW, Wang X, Liang DY. Comparison of three methods for the detection of Epstein-Barr virus in Hodgkin's lymphoma in paraffin-embedded tissues. Mol Med Rep. 2013;7(1):89-92.

10. Young LS, Deacon EM, Rowe M, et al. Epstein-Barr virus latent genes in tumour cells of Hodgkin's disease. Lancet. 1991:337:1617.

11. Grässer FA, Murray PG, Kremmer E, et al. Monoclonal antibodies directed against the Epstein-Barr virus-encoded nuclear antigen 1 (EBNA1): immunohistologic detection of EBNA1 in the malignant cells of Hodgkin's disease. Blood. 1994;84:3792.

12. Niedobitek $G$, Kremmer $E$, Herbst $H$, et al. Immunohistochemical detection of the Epstein-Barr virus-encoded latent membrane protein 2A in Hodgkin's disease and infectious mononucleosis. Blood. 1997:90:1664.

13. Glaser SL, Lin RJ, Stewart SL, et al. Epstein-Barr virus-associated Hodgkin's disease: epidemiologic characteristics in international data. Int J Cancer. 1997;70:375

14. Flavell $\mathrm{K}$, Constandinou C, Lowe D, et al. Effect of material deprivation on Epstein-Barr virus infection in Hodgkin's disease in the West Midlands. $\mathrm{Br}$ J Cancer. 1999:80:604-8.

15. Chang $\mathrm{KL}$, Albujar PF, Chen Y-Y, et al. High prevalence of Epstein-Barr virus in the Reed-Sternberg cells of Hodgkin's disease occurring in Peru. Blood. 1993:81:496-501.

16. Weinreb M, Day PJR, Niggli F, et al. The consistent association between Epstein-Barr virus and Hodgkin's disease in children in Kenya. Blood. 1996;87:3828-36.

17. Weinreb M, Day PJR, Niggli F, et al. The role of Epstein-Barr virus in Hodgkin's disease from different geographical areas. Arch Dis Child. 1996;74:27-31.

18. Herbst $H$, Steinbrecher $E$, Niedobitek $G$, et al. Distribution and phenotype of Epstein-Barr virus-harboring cells in Hodgkin's disease. Blood. 1992;80:484-91.
19. Armstrong AA, Alexander FE, Cartwright $R$, et al. Epstein-Barr virus and Hodgkin's disease: further evidence for the three disease hypothesis. Leukemia. 1998;12:1272-6.

20. Park CS, Juhng SW, Brigati DJ, Montone KT. Analysis of Epstein-Barr virus in Hodgkin's disease: experience of a single university hospital in Korea. J Clin Lab Anal. 1994;8:412-7.

21. Zhou XG, Hamilton-Dutoit SJ, Yan QH, Pallesen G. The association between Epstein-Barr virus and Chinese Hodgkin's disease. Int J Cancer. 1993:55(3):359-63.

22. Peh SC, Looi LM, Pallesen G. Epstein-Barr virus (EBV) and Hodgkin's disease in a multi-ethnic population in Malaysia. Histopathology. 1997;30(3):227-33.

23. Armstrong AA, Alexande RFE, Pinto Paes R, et al. Association of Epstein-Bar virus with paediatric Hodgkin's disease. Am J Pathol. 1993;142:1683-8.

24. Karnik S, Srinivasan B, Nair S. Hodgkin's lymphoma: immunohistochemical features and its association with EBV LMP-1. Experience from a South Indian hospital. Pathology. 2003:35(3):207-11.

25. Sughayer MA, Haddad HA, Al-Yousef RM, El-Khateeb M, Abu-Rass H. EpsteinBarr virus and Hodgkin lymphoma in Jordan. Hematol Oncol Stem Cell Ther 2014;7(2):85-9.

26. Fatima S, Ahmed R, Ahmed A. Hodgkin lymphoma in Pakistan: an analysis of subtypes and their correlation with Epstein Barr virus. Asian Pac J Cancer Prev. 2011;12(6):1385-8.

27. Swerdlow SH, Campo E, Harris NL, et al., editors. World Health Organization classification of tumours of haematopoietic and lymphoid tissues. Lyon: ARC Press; 2008

28. Siddiqui N, Ayub B, Badar F, Zaidi A. Hodgkin's lymphoma in Pakistan: a clinicoepidemiological study of 658 cases at a cancer center in Lahore. Asian Pac J Cancer Prev. 2006;7(4):651-5.

29. Chen YP, Zhang WN, Chen L, Tang LL, Mao YP, Li WF, et al. Effect of latent membrane protein 1 expression on overall survival in Epstein-Barr virus-associated cancers: a literature-based meta-analysis. Oncotarget. 2015;6(30):29311-23.

30. Park JH, Yoon DH, Kim S, Park JS, Park CS, Sung H, et al. Pretreatment whole blood Epstein-Barr virus-DNA is a significant prognostic marker in patients with Hodgkin lymphoma. Ann Hematol. 2016;95(5):801-8.

31. Dinand V, Sachdeva A, Datta S, Bhalla S, Kalra M, Wattal C, Radhakrishnan N. Plasma Epstein Barr virus (EBV) DNA as a biomarker for EBV associated Hodgkin lymphoma. Indian Pediatr. 2015;52(8):681-5.

32. Gahn TA, Schildkraut CL. The Epstein-Barr virus origin of plasmid replication, oriP, contains both the initiation and termination sites of DNA replication. Cell. 1989:58:527.

33. Thorley-Lawson DA, Gross A. Persistence of the Epstein-Barr virus and the origins of associated lymphomas. N Engl J Med. 2004;350:1328.

34. Jarrett AF, Armstrong AA, Alexander E. Epidemiology of EBV and Hodgkin's lymphoma. Ann Oncol. 1996;7 Suppl 4:5-10.

\section{Submit your next manuscript to BioMed Central and we will help you at every step:}

- We accept pre-submission inquiries

- Our selector tool helps you to find the most relevant journal

- We provide round the clock customer support

- Convenient online submission

- Thorough peer review

- Inclusion in PubMed and all major indexing services

- Maximum visibility for your research

Submit your manuscript at www.biomedcentral.com/submit
C) Biomed Central 